University of Nebraska - Lincoln

DigitalCommons@University of Nebraska - Lincoln

2004

\title{
A HISTORY OF LIBRARY ASSESSMENT AT THE UNIVERSITY OF NORTHERN COLORADO: FIFTEEN YEARS OF DATA ANALYSIS AND PROGRAM CHANGES
}

Lisa Blankenship

University of Northern Colorado, lisa.blankenship@unco.edu

Adonna Fleming

University of Nebraska-Lincoln, dfleming2@unl.edu

Follow this and additional works at: https://digitalcommons.unl.edu/libraryscience

Blankenship, Lisa and Fleming, Adonna, "A HISTORY OF LIBRARY ASSESSMENT AT THE UNIVERSITY OF NORTHERN COLORADO: FIFTEEN YEARS OF DATA ANALYSIS AND PROGRAM CHANGES" (2004). Faculty Publications, UNL Libraries. 300.

https://digitalcommons.unl.edu/libraryscience/300

This Article is brought to you for free and open access by the Libraries at University of Nebraska-Lincoln at DigitalCommons@University of Nebraska - Lincoln. It has been accepted for inclusion in Faculty Publications, UNL Libraries by an authorized administrator of DigitalCommons@University of Nebraska - Lincoln. 


\title{
A HISTORY OF LIBRARY ASSESSMENT AT THE UNIVERSITY OF NORTHERN COLORADO: FIFTEEN YEARS OF DATA ANALYSIS AND PROGRAM CHANGES
}

\author{
Lisa Blankenship and Adonna Fleming
}

\section{INTRODUCTION}

In 1985 the Colorado State Legislature mandated, in Article 13 of HB 1187 , that institutions of higher education become "accountable for demonstrable improvements in student knowledge, capacities and skills between entrance and graduation" (Colorado Revised Statutes, 1988). As a result, the University of Northern Colorado Libraries became involved in the assessment process. In 1988 the UNC Libraries formed the University Libraries Assessment Committee, comprised of library faculty, classified staff and an administrator in an ex officio position. The Assessment Committee conducted the first survey to assess user satisfaction in the fall of 1988. Since that time, the committee has conducted an assessment program on an annual basis. Today, the UNC Libraries are evaluated in three areas: collections, services, and instruction. Over time, the assessment tools and survey methodologies have evolved, and a variety of program changes have resulted. In this article, we will summarize the history of the assessment program at the UNC Libraries, track selected questions through the years, and describe the resulting changes in the UNC Libraries programs. 


\section{BACKGROUND}

The University of Northern Colorado was founded as the State Normal School in 1889 to train qualified teachers for the state's public schools. Its first class had 96 students who received teaching certificates after completion of two years of instruction. It became the State Teachers College of Colorado in 1911, with expanding its curriculum to support a fouryear Bachelor of Arts program. In 1935, the program was expanded again to include graduate programs, and the name was changed to Colorado State College of Education at Greeley. UNC achieved university status in 1970. The present mission of UNC is to offer a comprehensive liberal arts education at the baccalaureate level and master's and doctoral degrees primarily in the field of education. There are five colleges, Arts and Sciences, Education, Health and Human Sciences, the Monfort College of Business, and Performing and Visual Arts, with an approximate enrollment of 11,000 students.

UNC Libraries presently consists of two locations, the James A. Michener Library and the Music Library. In 1988, there was also a Laboratory School Library and Educational Materials Services. Michener, the main library, was named after writer James A. Michener, who attended UNC from 1936-1937 and taught as a Social Science educator from 1936 to 1941. His novel Centennial was conceived during his time at UNC. The building was opened in 1972 and its collections hold approximately 1.5 million items in monograph, periodical, government document, audiovisual and microform formats. Michener Library also houses the University Archives, the James A. Michener Special Collection, and the Mari Michener Art Gallery. Staffing includes 33 classified staff, 14 faculty, and three administrators.

The assessment program began in 1988 with the establishment of the University Libraries Assessment Committee. According to the first committee report (University Libraries Assessment Committee, 1989), the charge, as directed by Gary Pitkin, Dean of the UNC Libraries, was to "create, implement, and evaluate an assessment procedure at least annually. The results will be used by the University Libraries Administrative Staff to analyze and strengthen services provided to students, faculty and staff." Today, the committee is responsible for writing an annual plan outlining the upcoming year's activities and, at the end of the fiscal year, an annual report summarizing the survey results and including recommendations to program changes. In addition, the committee keeps a profile of its activities on the Libraries web site, including any program changes that have come about due to its recommendations. Outcomes and recommendations are accessed by Libraries Administration and become part of the Libraries' strategic planning process. The UNC Libraries undergo an official program review every five years from the UNC 
Administration. This review includes outcomes and recommendations made by the Assessment Committee over this time period, as well as the implementation of any recommendations to the program. Furthermore, data from the Assessment Committee reports is also collected for the university accreditation process conducted by the North Central Accreditation (NCA) organization.

\section{THE FIRST FIVE YEARS OF ASSESSMENT}

The first Assessment Committee decided to create a general library user survey and a separate faculty survey, both focusing on collections, services, and the environment in Michener Library and including basic demographic information such as UNC status (freshman through doctoral student, faculty, or staff), UNC college affiliation, sex, ethnicity, and age. Because the surveys had to be created in a brief amount of time, they did not include actual measurement of library skills, although the general library user survey did explore self-assessment of skill levels.

One of the committee goals was to gain an understanding of library users in terms of their awareness of library resources and services, their self-assessed success in using the library, and their general attitudes toward the library. The survey created for this purpose was handed out to 1500 people as they entered the library during the course of one day. The committee received 989 returned responses, a $66 \%$ return rate. The second goal of the committee was to gain an understanding of faculty perceptions of library resources and services relevant to library-related class assignments, library skills needed by students, and general attitudes toward the library. This survey was mailed to 551 teaching faculty at UNC, and 240 responses were received for a return rate of $44 \%$.

The committee found that, in general, those who reported more frequent library use also reported a higher level of skills and a greater awareness of services. In its final report (1989), the committee notes, however, that "self-evaluation of 'success' speaks to the self-confidence of the library users and may not be an accurate assessment of actual library skills of the respondents."

After the first year, the committee was referred to as the Library Assessment Committee (LAC), reflecting the fact that the survey focused on questions about using Michener Library and was distributed there. (Over the years, the questions have been broadened in scope and now refer to collections and services in the UNC Libraries as a whole.) With more time for preparation, the second survey was revised to include questions to actually measure library skills and compare this objective data with selfassessed skill levels. Efforts were focused on surveying general library users, since it was felt that a good base level of information had been col- 
lected from the previous faculty survey and that little would be gained from conducting another faculty survey so soon. This time, rather than including any questions measuring general user satisfaction with the library resources and services, the assessment was aimed at providing "a foundation for measuring changes made by students in the area of library literacy and to determine whether significant differences exist between the skills and knowledge of freshmen and seniors" (Library Assessment Committee [LAC], 1990). They identified library literacy according to the components listed in the Colorado Academic Library Master Plan (1988):

(1) Knowledge of the function and use of information sources.

(2) Ability to select relevant information.

(3) Knowledge of the physical arrangement of materials.

(4) Knowledge of the options available for utilizing local, state, regional and international systems.

The survey began with a few demographic questions followed by questions about frequency of library use, bibliographic instruction experiences, and a self-assessed rating of the respondent's library skills. Several questions about success in the use of specific materials and services were asked. Ten questions designed to objectively measure library skills concluded the survey. In a 1991 article in College \& Research Libraries, committee members noted that their literature search showed "that most library questionnaires geared to an academic population resemble UNC's 1988/1989 survey in principally addressing issues of user satisfaction relative to ambiance, quality of service, or access" (Greer et al., 1991), so this was new territory for the committee. The questions that they developed addressed the library literacy components from the Colorado Academic Library Master Plan listed above, ranging from questions about specific locations and services in the library to questions about selection of appropriate sources and structuring a database search. Surveys were distributed to arriving library users during the spring of 1990 (1000 distributed and 694 returned). Although "negative comments about the presence of test questions were written on some of the instruments or made when the surveys were returned" (Greer et al., 1991), the committee was generally pleased with the level of response and felt that the information collected from the survey was valuable. The self-assessment data showed definite trends toward higher scores for seniors as compared to freshmen. Although the tested knowledge levels for seniors were also higher than for freshmen, the increases were not as dramatic. The committee felt that the survey results demonstrated a need for more bibliographic instruction, and recommended that a new library faculty position be added for this purpose. The survey, with only minor changes, would be used for the next several years. 
An interesting follow-up to the 1990 survey was an analysis conducted during spring of 1991 after the annual survey was administered. Results from that year's survey were compared to those of a group of nursing students who had received a series of four library instruction sessions during one of their required courses and were given the same survey. In their conclusions, published in a 1993 Research Strategies article, the authors noted that bibliographic instruction did seem to play an important role in improving certain types of library skills (Fox et al., 1993).

In preparation for a library program review that takes place every five years, the 1992/1993 LAC prepared a report comparing the spring 1993 survey results with those from 1990, the first year that library skills were measured. Again, surveys were handed out at the door of Michener Library, but the rate of return had steadily dropped each year, and in 1993 only 337 of the 1000 distributed surveys were returned with enough of the questions completed to be usable. Judging by comments given by some library users as they were handed the surveys, people who had filled out the survey in previous years recognized it and weren't enthusiastic about being "tested" again. The survey remained largely the same through the years, but the format of some of the skills questions had been simplified. The average scores for the knowledge questions were significantly higher this time (LAC, 1993). For the revised questions, it was difficult to tell which had the greater effect, instruction efforts or the revised format. However, higher results were also seen on most of the questions that had not been revised. In particular, questions about constructing database searches showed considerable improvement. There was also an overall increase in self-reported excellent library skills (Table 1).

A Bibliographic Instruction Librarian position had been created and the entire instruction program had been revised along with the creation of new guides and handouts, so it was not surprising to see that participation in bibliographic instruction provided by a librarian increased. It was gratifying to see a particularly large increase in the numbers of students reporting excellent skills whose primary influence in library use

Table 1. Question: Using Computer Search Techniques on ERIC, Medline, Psyclit, Sociofile, or ABI/Inform, a Search Might Best be Constructed for the Topics as Shown Below.

1989/1990 -\% Correct 1992/1993-\% Correct

Topic: Child Abuse by Alcoholic Parents

Freshmen

Sophomores

Juniors

Seniors
46
42

67

61

68 
was a librarian-led class or handouts. The major programmatic recommendation from the committee was to explore ways to introduce more students to the library earlier. Revisions to the survey and exploring better methodologies for administering the survey to improve the response rate were also recommended.

During the first five years of Assessment Committee activities, a unique evaluation instrument was developed, and from the results recommendations were made. The most important of these, the addition of a Bibliographic Instruction Librarian position, resulted in a more active instruction program and more efforts to reach students earlier, which in turn led to improved library skills in UNC students.

\section{DEVELOPMENTS IN THE SURVEY AND THE METHODOLOGY}

During the 1995/1996 academic year, the LAC decided to rewrite the survey, eliminating the objective library skills questions. Because the library now had a well established bibliographic instruction program, it was felt that this type of assessment could be better handled in classroom settings with students attending instruction sessions. The new questionnaire focused on user experiences and attitudes with regard to Michener Library, particularly in terms of whether or not the collection supported curricular needs, student use of electronic resources, and satisfaction with public services. The format of the survey was updated as well, to include a machine readable response sheet to make the survey results easier to tabulate.

The original method of distributing the survey, handing it to people entering the library, had the disadvantage of only reaching library users. The LAC was also interested in learning something about members of the campus community who were not regular library users. In an effort to get information from a broader section of the campus, the 1995/1996 LAC decided, in addition to handing the surveys out at the library door, to distribute surveys at the University Center and the various cultural centers on campus (such as the International Student Center). Ultimately, the committee didn't feel that handing out the surveys in different locations was particularly successful.

\section{Teaming with a Marketing Class}

The 1996/1997 LAC decided to make a complete change in the process. Committee members had long felt that it would be desirable to give the survey in a setting that would encourage respondents to answer more 
thoughtfully and thoroughly. The LAC enlisted a Marketing class on campus to conduct the library survey as part of a class project. The Marketing students created a survey, with input from the LAC members and from various groups of students through focus group interviews, and distributed it to classes with enrollments providing a representative sample of the undergraduate population at UNC. This method had the advantage of giving the library a chance to survey students within a classroom setting and giving the students a real-life project to manage.

One of the interesting aspects of having students take a large role in developing the survey was that questions were asked that the LAC had never before thought of asking. For example, the Marketing students included questions about how safe students felt in the library and walking from and to the parking lot. Interestingly, this turned out to be of great concern to many students who evidently didn't feel safe walking between the library and the parking lot after dark. The experience of working with the Marketing class was generally successful, although the LAC members felt that they would like to have had more input on the wording of the questions (LAC, 1997). This same procedure was used the following year, and with a year of experience, the survey was edited more carefully and the chair of the LAC was able to contribute a final proof-reading.

\section{Surveying Faculty}

Beginning with the 1998/1999 academic year, the LAC decided to once again survey the faculty. It had been ten years since the first survey, which included a version that was mailed to all faculty members on campus. Since that time, the survey had targeted the undergraduate population. The LAC decided to try alternating the populations surveyed each year, with the 1998/1999 survey given to faculty and graduate students, then the 1999/2000 survey given to undergraduates, and so on. That pattern was followed for four years.

The faculty surveys for 1999 and 2001 were mailed to faculty members, and the return rate both years was approximately $23 \%$. Survey questions focused on the library collections, satisfaction with staff, and instruction services. In 1999, the LAC members were not surprised to see disappointing numbers of faculty respondents reporting that the collections supported their own professional research (of those with an opinion, there were $52 \%$ positive responses about the monograph collection and $55 \%$ about the journal collection). They were slightly more positive about whether the collection supported their students' needs. They were very positive about the assistance efforts of the library staff (over $96 \%$ positive responses). When asked about library instruction, $46 \%$ reported 
scheduling a library instruction session, with $94 \%$ of those reporting that the session was very useful or somewhat useful, $78 \%$ reporting that the session was also useful to their own research, and $68 \%$ reporting a difference in the quality of student work as the result of the library instruction session (LAC, 1999). The 2001 results were similar.

\section{Continuing Evolution of the Student Survey}

Although the LAC no longer partnered with the Marketing class for the undergraduate or the graduate surveys, they did continue to administer the surveys to classes with populations reflecting the makeup of the overall UNC population, as selected by the UNC Institutional Research office. Rather than continuing to collect demographic information as part of the survey, the committee decided to ask students to supply student ID numbers. Institutional Research was then able to provide accurate demographic information, including information that had not been previously collected on the library surveys, such as cumulative grade point average. After receiving the list of classes from Institutional Research, the LAC contacted the professors for the classes and set up times to give the surveys. Occasionally, a faculty member would not give permission to the LAC to give the survey in a particular class, usually due to inflexibility of class plans during the survey period. This sometimes resulted in the oversampling of students in certain colleges and under-sampling in others.

The 1996 survey omitted the questions that objectively assessed library skills, but because the LAC was interested in measuring information literacy skills in a variety of ways, they were reinstated for the 2000 undergraduate survey. Five multiple choice questions about basic information seeking techniques were included, covering skills such as understanding the purpose of a periodical index and the library catalog, using Library of Congress subject headings, and finding items if they are not available in the UNC Libraries collections. In the past, the committee received negative comments about the existence of "test" questions on the survey, but that was no longer the case once the survey was administered by LAC members in classroom settings. In this setting, a verbal explanation could be given about the fact that these questions were included so that the Libraries' faculty members could gauge the effectiveness of their instruction efforts.

\section{Updating the Assessment Plan}

In 1999/2000, the LAC also updated and expanded the assessment plan. According to the assessment report on that year's undergraduate survey, 
the committee planned to collect data to be used to evaluate the UNC Libraries with these objectives in mind:

(1) Ensure that library resources support class assignments, professional research, and other types of UNC scholarship.

(2) Provide our users with superior assistance in finding and using information from internal collections as well as remote resources.

(3) Increase user awareness of library resources and services in a rapidly evolving information environment.

(4) Maximize the information literacy skills of students and faculty to enable them to become effective library users, information consumers, and lifelong learners (LAC, 2000).

This data has been collected through the continued use of the annual survey, along with pre- and post-tests given through the library instruction program. The LAC encouraged the future use of a wider variety of assessment activities. As a response to the expanded assessment plan, LAC invested in two new assessment tools in 2003, LibQUAL, an online web survey, and the Automated Collection Assessment and Analysis Service (ACAS) from OCLC.

\section{Moving to an Online Survey for 2003}

Instead of conducting the faculty survey for the spring of 2003, LAC chose to participate in the LibQUAL+ project. LibQUAL+ is a webbased library assessment survey sponsored by the Association of Research Libraries (ARL) in collaboration with the Texas A\&M University Libraries. This survey instrument measures user satisfaction in terms of the collection, facilities and service. It is based on the SERVQUAL survey instrument which utilizes the "Gap Theory of Service Quality" and was developed by the marketing research team of A. Parasuraman, V. A. Zeithaml, and L. L. Berry. The focus of LibQUAL is to measure service quality. The instrument measures the library users' perceptions of service quality and identify gaps between desired, perceived and minimum expectations of service and assigns quantifiable variables to the outcomes.

LAC chose to replace the in-house survey with LibQUAL for a variety of reasons. First, LibQUAL has the advantage of allowing participants to compare their results with other participating institutions around the country. In 2003, 316 academic libraries, including several Colorado institutions, were participating in LibQUAL, and, since the University would be undergoing its ten year accreditation process from NCA in 2004, LAC felt it was imperative to have comparative data from peer institutions. 
Secondly, the committee thought that an online survey would reach more of the Libraries' users, specifically off campus students and faculty. Thirdly, LAC thought that an online survey, which could be taken from the convenience of a computer anywhere and at anytime, would be perceived easier to take, and thus more amiably received. Finally, LAC felt that once the parameters were set up to use LibQUAL on an annual basis, the committee would have to spend less time implementing the survey and analyzing the outcomes than they did with the in-house version. This was an important issue due to the staff reductions and budget cuts the Libraries were facing.

LAC opened LibQUAL+ to the UNC community for a three week period beginning March 31, 2003, with the expectation that the results would be available from ARL sometime in the summer of 2003. For the first year, they wanted to reach as much of the UNC community as possible, and made it available to all faculty, staff and students. (Library faculty and staff were welcome to take the survey, but their answers would be excluded from the analysis.) The UNC community was notified about the survey through a series of email announcements, and advertising both in the University's newspaper as well as posters within the Libraries. Incentive gifts, such as pizza coupons, were offered to qualified participants. The UNC community could access the survey from the Libraries webpage as well as the email notices. Through LibQUAL+, LAC was able to reach larger numbers of UNC community members than through the printed surveys.

\section{OCLC ACAS Project}

Although showing a slight improvement between the 1999 and 2001 faculty/ graduate student surveys, the negative responses relating to the quality of the monograph collection were still high enough to cause concern. In 1999, $48.1 \%$ reported dissatisfaction with the collection, followed by $31.6 \%$ in 2002. Whereas the implementation of Prospector, a union catalog which includes libraries in Colorado and Wyoming from which UNC faculty and students may borrow books and have them delivered to UNC, has relieved some of this negativity, LAC decided it was time to assess the monograph collection and look for subject areas that were inadequate to support UNC curriculum needs.

LAC contracted with OCLC in the fall of 2002 to perform an automated analysis of UNC Libraries' collection based on the holdings in the online catalog. OCLC provided LAC with a title list arranged by WLN (Western Library Network) Conspectus subject levels: 24 divisions, 500 categories and 4,000 subject descriptors. The titles were categorized by subject and broken out by publication date. In addition, OCLC also provided a sepa- 
rate analysis of the classified serials as well as a comparison of UNC's titles to the Choice Outstanding Academic Books lists from 1991 through 2002.

LAC plans to use this data to recommend changes to the collection development formula which is currently undergoing review. In addition, subject bibliographers will be able to use the data to request special funds from the James A. Michener Endowment to fill in some of the weak areas in their respective subject areas.

\section{TRENDS IN RESPONSES}

Responses were easy to compare during the first several years of assessment activities because the survey wasn't significantly altered, but many changes have been made to the instrument in subsequent years. The early versions focused on library skills, with a change to general user satisfaction questions in the 1996 survey. Each year, the survey has been revised, sometimes slightly and sometimes in major ways, to reflect the interests of the current LAC members and the changes happening in the library with regard to collections and services.

Since 1996, questions about the services provided by the library faculty, staff, and student employees have always been included, and these questions have always yielded large percentages of positive results. Demographic information has been collected since the beginning, either through questions or through information provided by Institutional Research, and results for the other questions have been cross-tabulated with this information. The results have never shown any particular long term trends or differences with respect to ethnicity or gender. Occasionally, differences emerged in a particular survey, for example, the 1998 survey showed that female students and older students were more likely to ask for assistance.

Technological advances resulted in the addition of certain questions. For example, a question about whether or not the respondent has used the Internet for class-related research first appeared on the survey in 1996, with approximately $45 \%$ answering yes. That question has been asked in all subsequent undergraduate and graduate student surveys, and not surprisingly, the positive responses increased (Table 2).

Another change was seen when the Libraries migrated to a new integrated library system. In the 1996 survey, many respondents reported unhappiness with their experiences with our text-based online catalog and article indexes. Comments suggested that the systems were complex, unfriendly, and slow. In 1998, after the Libraries migrated to a new system, $70 \%$ of the respondents reported that both the catalog and the article indexes were easy to use.

During the first several years, the question "How often have you used the library in the past year" was asked. Choices were almost daily, once 
Table 2. Percent Reporting Use of the Internet for Class-Related Research.

\begin{tabular}{ll}
\hline Year & $\%$ \\
\hline $1995 / 1996$ & 44.8 \\
$1996 / 1997$ & 60 \\
$1997 / 1998$ & 86.4 \\
$1998 / 1999$ & 90.5 (graduate students) \\
$1999 / 2000$ & 98.2 (undergraduates) \\
$2000 / 2001$ & 93.7 (graduate students) \\
$2001 / 2002$ & 98.3 (undergraduates) \\
\hline
\end{tabular}

a week, once a month, and occasionally. The responses showed that approximately $70 \%-80 \%$ of undergraduates were daily or weekly library users. The 1998 survey was updated to measure the number of times students used the library's collections for class-related research rather than measuring physical presence in the library. This made sense as many of the library resources and services had become available remotely. In spite of the large numbers of students using the Internet for research, the library's collections are still heavily used. In 1998, over $96 \%$ of the undergraduates reported at least some use of the library's collections for class-related research. This number dropped to $91.5 \%$ in 2000, and rose to $93.3 \%$ in 2002 . Another interesting finding in the 2000 report came from comparing frequency of use of the library's collections for class-related research to cumulative grade point average. There appeared to be "a clear relationship between the use of library resources and cumulative GPA" (LAC, 2000). The exception came in the most frequent use category (16+ times), but further analysis showed that many respondents in this group had not actually been given regular admittance status to the University, but were part of a program that includes extensive tutoring (including many library visits) to prepare students for regular admittance. The original question included use of the library for purposes other than use of library collections. In the 2002 survey, the LAC decided to look at the variety of reasons that students use the library. Students were asked about their use of the libraries and library resources, and use of the libraries' computers. Results (LAC, 2002) showed that the main use of the libraries was for course related research $(84.3 \%)$, followed by use as a place to study $(63.3 \%)$, use of reserve readings $(44.6 \%)$, use as a computer lab $(39.3 \%)$, and as a place to socialize (7.2\%). The computers were used most frequently to access library resources (93.8\%), followed by use for course related web use $(56.4 \%)$, email use $(50.2 \%)$, Microsoft Office software $(43 \%)$, and recreational web browsing $(35.1 \%)$.

When questions objectively measuring library skills were asked, results have demonstrated that library instruction has a positive effect on 
Table 3. Survey Results.

\begin{tabular}{|c|c|c|c|}
\hline Year & $\begin{array}{c}\text { Number of } \\
\text { Instruction Sessions }\end{array}$ & $\begin{array}{l}\text { \% Having Had a Library } \\
\text { s Instruction Session }\end{array}$ & Notes \\
\hline $1989 / 1990$ & 199 & 53 & First year question was asked. \\
\hline 1992/1993 & 217 & 63 & $\begin{array}{l}\text { A } 0.75 \text { FfE Instruction Librarian } \\
\text { was added. }\end{array}$ \\
\hline 1996/1997 & 182 & 42 & $\begin{array}{l}\text { Instruction Librarian used elec- } \\
\text { tronic tutorial for some classes. }\end{array}$ \\
\hline $1997 / 1998$ & 242 & 61 & $\begin{array}{l}\text { FTE was added to the Instruction } \\
\text { Department during the year. }\end{array}$ \\
\hline $1999 / 2000$ & 205 & 49 & $\begin{array}{c}\text { Instruction Librarian focused } \\
\text { on creating LID } 150 \text { course. }\end{array}$ \\
\hline
\end{tabular}

library skills. This was noted in the 1993 Research Strategies article (Fox et al., 1993) and in the LAC report of 1993 that compared 1990 and 1993 survey results (LAC, 1993). In the report of the undergraduate survey of 2000, an interesting comparison was done among participation in library instruction, attitude toward the instruction, and the results of the objective questions. The highest number of correct responses (67.6\%) was for the question "What resource should you consult to determine if UNC Libraries owns a particular book." The lowest number (14.1\%) was for the question "When searching for books in Michener Library, how can you determine the official subject heading(s) for your topic." The results were cross-tabulated, and showed that having attended a library instruction session greatly increased the likelihood of answering certain questions correctly ("When searching for books in the Michener Library, how can you determine the official subject heading(s) for your topic," "What is the BEST procedure to follow if UNC Libraries does now own a magazine or journal article that you need," and "Which is an advantage of subject heading searches"). Of those who had not received library instruction, the average number of correct answers out of the five questions was 2.13. For those who had library instruction, the average score was 2.48. For those who had library instruction and reported that they found it helpful, the average score was 2.52, compared to 2.35 for those who had library instruction but didn't feel that it was useful (LAC, 2000). The next year, in the report of the 2001 graduate student survey (LAC, 2001), results were similar.

Questions about library instruction services have been asked most years since the 1990 survey. That year, 53\% of the survey respondents ( $45 \%$ of the freshmen and $68 \%$ of the seniors) reported having participated in a bibliographic instruction session provided by a librarian. By 1993, with the addition of a more formal instruction program, the numbers increased to $63 \%$ (50\% of the freshmen and $71 \%$ of the seniors) (Table 3 ). 
Since then, the results have shown significant rises and falls. The survey results wouldn't necessarily be expected to mirror the actual numbers of library instruction sessions held during a particular year since the question asked about past instruction experiences and not only instruction experiences during the current year. However, the actual statistics do show similar variations, mostly explained by programmatic and staffing changes. The rate of change is not the same for the survey results as for the actual statistics though, and this suggests the importance of collecting statistical information and assessment data in a variety of ways.

\section{CHANGES BASED ON SURVEY OUTCOMES}

Several changes to the Libraries' program have been made based on the recommendations of the LAC committee. Following is a chronological order of the most significant.

1989 - LAC recommended an increased emphasis in library instruction and a bibliographic instruction librarian was hired in the fall of 1990.

1996 - LAC recommended increasing efficiency and stability of the online catalog or replacing it, and as a consequence, UNC Libraries contracted in the fall of 1997 with Innovative Interfaces, Inc. to provide the online catalog. In the same year, based on the LAC recommendation to provide public Internet access, four Internet workstations were added to the reference area.

1997 - LAC recommended that, since the library has taken a leading role in providing expertise for accessing Internet based information to UNC, we should promote our expertise and make Internet access more visible to students. Many did not know whether or not the Internet was available in the library but reported that they would probably use it if it was. As a consequence, the Libraries increased the number of computers in the library and more librarians began presenting information about web use in bibliographic instruction classes. In addition, the Libraries started providing online document delivery of journal articles through Uncover, and later Ingenta.

1998 - Three changes were made based on the 1998 survey. First, LAC wanted to assess interest in a credit-bearing information literacy course. The results showed that $38.5 \%$ of those surveyed responded positively, and, because the Libraries were only investigating the possibility of offering one or two sections of such a class, this was deemed enough of a positive response. In 2000, it was $44.5 \%$. The class was offered beginning fall of 2000.

Secondly, gradual changes in the food and drink policy were implemented based on the 1998 survey. Students were asked to rank which of 
the following they would like to see added. Responses included: Room where eating and drinking are allowed - $26 \%$; open computer lab - 46\%; more individual and group study space $-25 \%$. As a result students are allowed to have food and drink on the first floor and a coffee cart is planned for the summer of 2003.

Thirdly, in response to the same question, the Information Commons was established in the fall of 2000. Beginning with eight computers, this area was established as a place where students could work on research assignments. Each computer workstation has a fully functional computer offering Internet access, email and Microsoft Office, as well as the Libraries online resources. The area was upgraded to 16 computer workstations in the fall of 2001 and 32 in the summer of 2002. In January 2003, Microsoft Office was added to 15 of the 30 existing Internet-only computers in Reference.

1999 - To address collection deficiencies that had been noted over a number of years, the UNC Libraries became a member of the Prospector union catalog. This catalog combines the holdings of the 16 academic libraries in Colorado and Wyoming as well as Denver, Jefferson County and Fort Collins public libraries. Patrons may search this catalog and request books that their home library does not own.

2000 - LAC recommended that the committee monitor data from national surveys and use it to supplement and inform our other assessment activities. As a result, the Libraries joined the LibQUAL+ online national survey project in 2003.

2002 - Over the years there has been increasing demand to provide more study space and upgrade furniture. In 1998, 25\% of those surveyed selected "more individual and group study space" as a priority. In 2002, from a list of four options, 25\% requested a 24 hour study area, and $11 \%$ wanted to replace existing furniture with updated furniture. In response, the Libraries formed a Furniture Task Force to look at purchasing new furniture, investigate compact shelving, and re-group the current furniture to create more study space. Presently, the Libraries have received $\$ 75,000$ to reupholster and replace some of the existing furniture.

\section{CONCLUSION}

For the past 15 years the UNC Libraries have been involved in assessment. Although the methodology and the instrument have gone through many changes, the focus has not. Users have been asked in one form or another to evaluate the Libraries in terms of service, collections, and instruction. In response to these evaluations, the Libraries have instituted many changes over the years; the most significant include focusing on in- 
struction and information literacy through the hiring of a bibliographic instruction librarian in 1990 followed by implementing LIB150, a creditbearing course, in the fall of 2000 . To respond to the ever-increasing demand for computer access and the importance electronic resources play in information gathering, the Libraries developed the Information Commons in 2000. This area allowed students to access information, evaluate it, and compose their research papers all within the library. Finally, in response to collection deficiencies, the Libraries became a member of the Prospector union catalog, thus allowing academic libraries in Colorado and Wyoming to share access to their collections, a must in these economic times.

\section{REFERENCES}

Colorado Academic Library Committee (1988). Colorado academic library master plan (3rd ed.). Denver: Colorado Commission on Higher Education.

Colorado Revised Statutes (1988). Section 23-13-101.

Greer, A., Weston, L., \& Alm, M. (1991). Assessment of learning outcomes: A measure of progress in library literacy. College \& Research Libraries, 52, 549-557.

Library Assessment Committee (1990). Second annual library assessment committee report. Greeley: University of Northern Colorado, University Libraries.

Library Assessment Committee (1993). Library assessment committee report, 1992-1993. Greeley: University of Northern Colorado, University Libraries.

Library Assessment Committee (1997). Spring 1997 student survey report. Greeley: University of Northern Colorado, University Libraries.

Library Assessment Committee (1999). Report on the annual user survey. Greeley: University of Northern Colorado, University Libraries.

Library Assessment Committee (2000). Report on the undergraduate survey 2000. Greeley: University of Northern Colorado, University Libraries.

Library Assessment Committee (2001). University libraries assessment plan. Greeley: University of Northern Colorado, University Libraries.

Library Assessment Committee (2002). Report on the undergraduate survey 2002. Greeley: University of Northern Colorado, University Libraries.

University Libraries Assessment Committee (1989). Final 1988-1989 report. Greeley: University of Northern Colorado, University Libraries. 